\title{
Analysis of the functional properties of the creatine kinase system using a multiscale 'sloppy' modeling approach
}

\author{
Hannes Hettling ${ }^{1 *}$, Jaap Heringa ${ }^{1}$, Johannes HGM van Beek ${ }^{1,2}$ \\ From Sixth International Society for Computational Biology (ISCB) Student Council Symposium \\ Boston, MA, USA. 9 July 2010
}

\section{Background}

Distinct functions have been hypothesized for the creatine kinase (CK) enzyme catalyzing the reversible transfer of the high-energy phosphate group of ATP to creatine. In muscle cells, two CK isoforms might mediate (i) temporal energy buffering to maintain ATP homeostasis and (ii) energy transport from mitochondria to myofibrils via the "phosphocreatine shuttle" mechanism. Here we investigate the relative importance of the two roles using a computational model [1]. Model simulations predict a contribution of CK to the net transcytosolic energy transport of less than $1 / 3$.

\section{Materials and methods}

The model is validated on experimental data from two scales: kinetic parameter measurements on the enzyme level and response times of oxidative phosphorylation in whole cardiac muscle.

To account for possible inaccuracies in the 22 model parameters, we sample a Bayesian ensemble of parameter sets which allows us to set confidence regions on model predictions. In this 'sloppy' modeling approach [2], the likelihood of a parameter combination to be included in the ensemble is proportional to its likelihood to predict the data. We use prior information on single parameter values from enzyme kinetic measurements to constrain them within their measurement errors.

\footnotetext{
* Correspondence: hettling@few.vu.nl

${ }^{1}$ Centre for Integrative Bioinformatics VU (IBIVU), VU University, Amsterdam, The Netherlands

Full list of author information is available at the end of the article
}

\section{Results}

From the ensemble, we predict a contribution of CK to the overall energy transport of $15 \pm 8 \%$ (mean \pm SD). The CK system damps the pulses of ATP hydrolysis of 3765 $\mu \mathrm{M}^{*} \mathrm{~s}^{-1}$ during cardiac systole about 20 fold. CK inhibition by $98 \%$ increases the amplitude of ATP synthesis from $215 \pm 23$ to $566 \pm 31 \mu \mathrm{M}^{*} \mathrm{~s}^{-1}$ (see Figure 1).

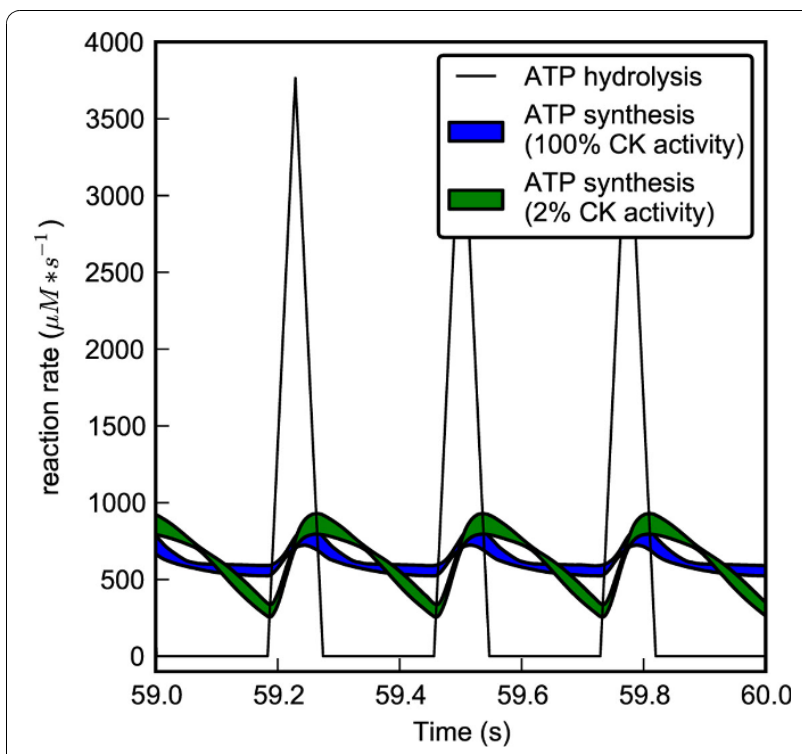

Figure 1 Prediction of ATP synthesis rate for full CK activity and CK inhibition by $98 \%$. The plot shows the steady state values of the last second of a simulation over 60 seconds. Note that the plotted regions show the $95 \%$ confidence interval between upper and lower bound of the simulation of a parameter ensemble containing 500 parameter sets. Model input is a forcing function simulating pulsatile ATP hydrolysis in the beating heart, plotted in black.

\section{() Biomed Central}




\section{Conclusion}

Our findings clearly support the hypothesis that CK acts as a high capacity temporal energy buffer damping energy peaks rather than being an essential energy transport system.

\section{Author details}

${ }^{1}$ Centre for Integrative Bioinformatics VU (IBIVU), VU University, Amsterdam, The Netherlands. ${ }^{2}$ Department of Clinical Genetics, VU University medical centre, Amsterdam, The Netherlands.

Published: 7 December 2010

\section{References}

1. van Beek $\mathrm{H}$ J: Adenine nucleotide-creatine-phosphate module in myocardial metabolic system explains fast phase of dynamic regulation of oxidative phosphorylation. Am J Physiol Cell Physiol 2007, 293: C815-C829.

2. Gutenkunst RN, Waterfall JJ, Casey FP, et al: Universally sloppy parameter sensitivities in systems biology models. PLoS Comput Biol 2007, 3:1871-1878

\section{doi:10.1186/1471-2105-11-S10-09}

Cite this article as: Hettling et al:: Analysis of the functional properties of the creatine kinase system using a multiscale 'sloppy' modeling approach. BMC Bioinformatics 2010 11(Suppl 10):O9.

\section{Submit your next manuscript to BioMed Central} and take full advantage of:

- Convenient online submission

- Thorough peer review

- No space constraints or color figure charges

- Immediate publication on acceptance

- Inclusion in PubMed, CAS, Scopus and Google Scholar

- Research which is freely available for redistribution

Submit your manuscript at www.biomedcentral.com/submit 